
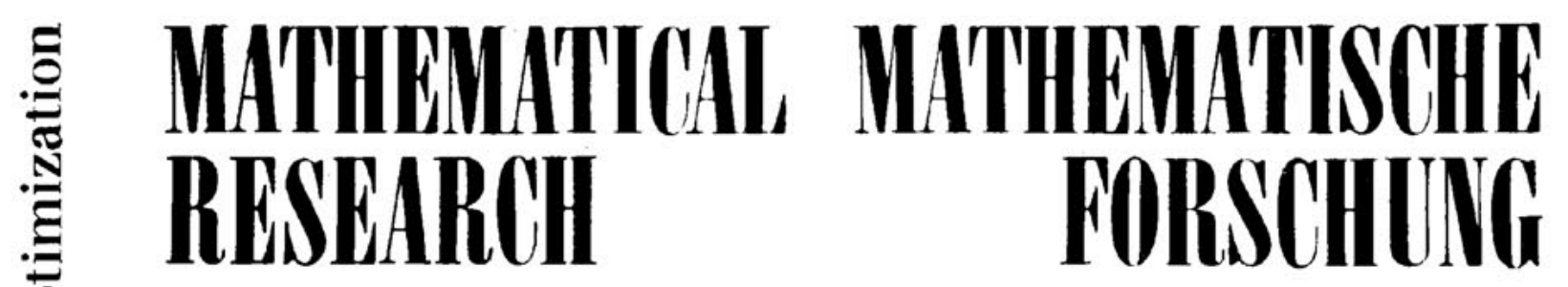

ธิ

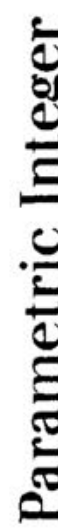

Parametric Integer Optimization

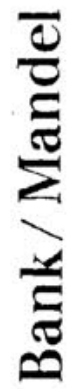

B. Bank/R. Mandel

\title{
Band 39
}

39 Akademie-Verlag Berlin 
In this series original contributions of mathematical research in all fields are contained, such as

- research monographs

- collections of papers to a single topic

- reports on congresses of exceptional interest for mathematical research.

This series is aimed at promoting quick information and communication between mathematicians of the various special branches.
In diese Reihe werden Original-

beiträge zu allen Gebieten der mathematischen Forschung aufgenommen wie

- Forschungsmonographien

- Sammlungen von Arbeiten zu einem speziellen Thema

- Berichte von Tagungen, die für die mathematische Forschung besonders aktuell sind.

Die Reihe soll die schnelle Information und gute Kommunikation zwischen den Mathematikern der verschiedenen Fachgebiete fördern.
Manuscripts

in English and German comprising at least 100 pages and not more than 500 pages can be admitted to this series. With respect to a quick publication the manuscripts are reproduced photomechanically. Authors who are interested in this series please turn directly to the 'Akademie-Verlag'. Here you will get more detailed information about the form of the manuscripts and the modalities of publication.
Manuskripte

in englischer und deutscher Sprache, die mindestens 100 . Seiten und nicht mehr als 500 Seiten umfassen, können in diese Reihe aufgenommen werden. Im Interesse einer schnellen Publikation werden die Manuskripte auf fotomechanischem Weg reproduziert. Autoren, die an der Veröffentlichung entsprechender Arbeiten in dieser Reihe interessiert sind, wenden sich bitte direkt an den Akademie-Verlag. Sie erhalten dort genauere Informationen über die Gestaltung der Manuskripte und die Modalitäten der Veröffentlichung. 